\title{
Hydrochemical Approach to Groundwater in the Environment of the Public Discharge of Lake Mbeubeuss (Dakar, Senegal)
}

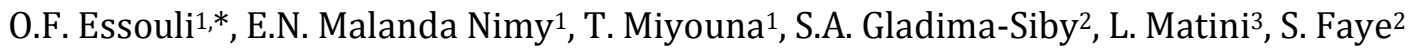 \\ ${ }_{1}^{1}$ Marien NGOUABI University, Faculty of Science and Technology, Geoscience Laboratory, B.P. 69 Brazzaville, Congo. \\ ${ }^{2}$ Cheikh Anta Diop University, Faculty of Science and Technology, Geology Département, B.P. 743 Dakar-Fan, Sénégal. \\ ${ }_{3}^{3}$ Marien NGOUABI University, Superior Normal School, Chemistry Laboratory, B.P. 69 Brazzaville, Congo.
}

\section{ART T C LE DETAILS}

\section{Article history:}

Received 09 November 2021

Accepted 14 December 2021

Available online 07 January 2022

\section{Keywords:}

Mbeubeuss Lake

Public Discharge

Mineralization

Hydrochemistry

Groundwater

\begin{abstract}
A B S T R A C T
To determine the origin and the processes of groundwater mineralization in the Mbeubeuss lake area, the major ion concentrations of the groundwater were compared to those of the rainwaters which constitute the input function of the aquifer of the Quaternary sands in the area of lake Mbeubeuss. The physico-chemistry of groundwater near the public discharge and its surroundings, has shown that the true value of the electrical conductivity of waters are around $2000 \mu \mathrm{S} / \mathrm{cm}$. Values of electrical conductivity greater than $2000 \mu \mathrm{S} / \mathrm{cm}$ would represent the particular mineralization of ground waters by the public discharge of lake Mbeubeuss. The chemical facies of ground waters are dominated by the sodium and potassium chloride and calcium chloride facies. The study of the relationship between the major chemical elements and the chloride ion and the representation in the modified Chadha diagram of the chemical analyzes of ground waters from the campaigns of July 1998, July 2002 and March 2003, made it possible to highlight the different sources and processes controlling the mineralization of ground waters in the Mbeubeuss Lake area. Despite the proximity to the sea which suggests a considerable contribution of salts by aerosols and sea spray, the mineralization of ground waters in the area of lake Mbeubeuss is largely due to leachate from household waste and the influence of old sediments of the dry lake Mbeubeuss. The main processes controlling the mineralization of ground waters are marine contributions (aerosols and sea spray), dissolution-precipitation of minerals from the aquifer matrix, atmospheric $\mathrm{CO}_{2}$ diffusion, base exchanges, dilution-concentration and anthropogenic pollution.
\end{abstract}

\section{Introduction}

In semi-arid to arid zones, the sustainability of groundwater resources generally depends on climatic and anthropogenic factors. In fact, population growth and the effects of climate change have greatly increased the pressure on water resources $[1,2]$.

The consumption of polluted water by populations contributes to the development of water-borne diseases due, among other things, to pathogenic germs, carcinogenic products and nitrogen compounds. If immediate corrective actions are not taken, the contamination of ground waters will cause a shortage of drinking water in the years to come [3].

The deterioration of the quality of water resources by the proliferation of different sources of pollution (fertilizers and pesticides, discharge of untreated wastewater, discharge of uncontrolled solid waste, mining, urbanization, etc.) also constitutes a threat important than that linked to the quantitative imbalance. This situation has required new approaches to water scheduling and management [4].

The water table of Quaternary sands belonging to the Dakar region is an example of a water table subject to anthropogenic constraints [5-7]. This water table has been under the influence of strong anthropization for several years: demographic explosion in the city of Dakar and the overexploitation of water resources to meet the increased demand for drinking water supply in the city of Dakar and surroundings. This state caused a sharp drop in the piezometric level and pollution of the water table by nitrates. The identification of sources of mineralization becomes, in this case, essential for developing water resource management plans in the context of climate variability $[8,9]$.

Monitoring groundwater around municipal household waste storage sites is an essential aspect of the proper management of these sites and the protection of the environment. At the scale of the study region, the evaluation of the physico-chemical quality and the origin of the mineralization of groundwater in the face of the various constraints remain questions for which this work proposes to provide some answers likely to subsequently help organizations in charge of water resources management in decision-making. Based on hydrogeological and hydrogeochemical methods, the present study aims to determine the origin and the processes that govern the mineralization of groundwater in the area of lake Mbeubeuss in connection with the public discharge of lake Mbeubeuss.

\section{Experimental Methods}

\subsection{General Presentation of the Study Area}

The Dakar region represents the extreme western tip of Senegal and of Africa. The Mbeubeuss lake sector is located about thirty kilometers from the city of Dakar, between latitudes $14^{\circ} 47^{\prime}$ and $14^{\circ} 50^{\prime}$ North and longitudes $17^{\circ} 16^{\prime}$ and $17^{\circ} 20^{\prime}$ West as presented in Fig. 1.

Nowadays, the stratigraphy of the Dakar region is very well known because of several oil and hydraulic boreholes carried out (Fig. 2) and highlights formations dated from the Upper Cretaceous (Maastrichtian) to the Quaternary of which only the Quaternary formations present a hydrogeological interest $[10,11]$.

The quaternary sands aquifer system extends from the great Niaye of Pikine to lake Tanma. The Quaternary sands are on a Tertiary marl-clayey substratum, the configuration of which will influence the flow of groundwaters. In addition, the interruption of the sedimentation of sandy deposits by the formation of clay-sands and sandy-clays from marine transgression, causes the aquifer of the Quaternary sands to be subdivided into several layers. The aquifer, entirely free, has a few very limited semicaptive aquifers [10-12].

The morphology of the aquifer bottom is relatively troubled, overall the top of the marls sinks towards the north coast in the area of Lake Mbeubeuss and towards Lake Retba, as it rises between Cap des Biches 
and Niakoul Rap. The thickness of the sands aquifer is highly variable, depending on variations in the morphology of the substratum (Fig. 3) [1012].

The significant thicknesses of the wet sands in the depressions shaped by erosion follow the main tectonic lines. There are fossil valleys and lake basins, the most important of which, the Thiaroye basin and the Beer Thialane depression, constitute the main collection centers for the exploitation of this aquifer $[11,12]$.

Due to the great variability in the geometry of the quaternary sands aquifer, the hydrodynamic parameters also present a spatial variability. The transmissivities vary from 2.45 to $6.75 .10^{-4} \mathrm{~m}^{2} / \mathrm{s}$, the permeabilities of the order of 0.40 to $7.40 .10^{-4} \mathrm{~m} / \mathrm{s}$ and the storage coefficient ranging from 1.06 to $2,51 \%$ [7].

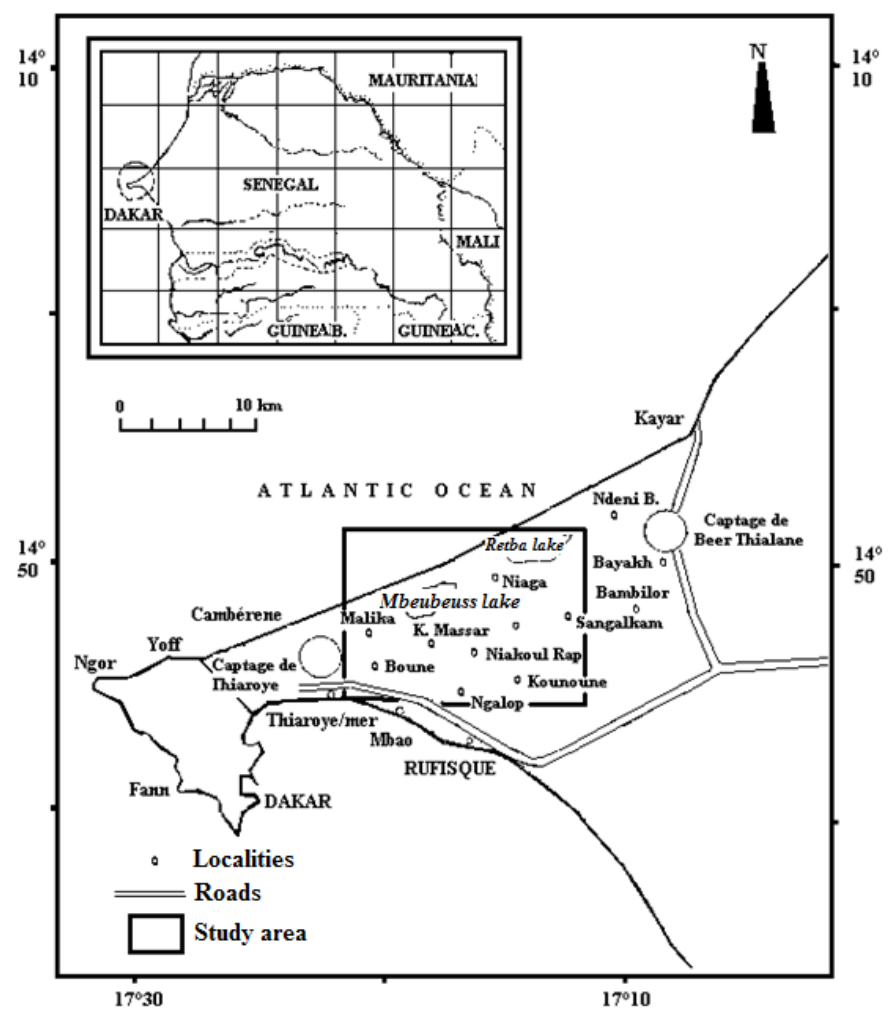

Fig. 1 Geographic situation of Mbeubeuss lake area

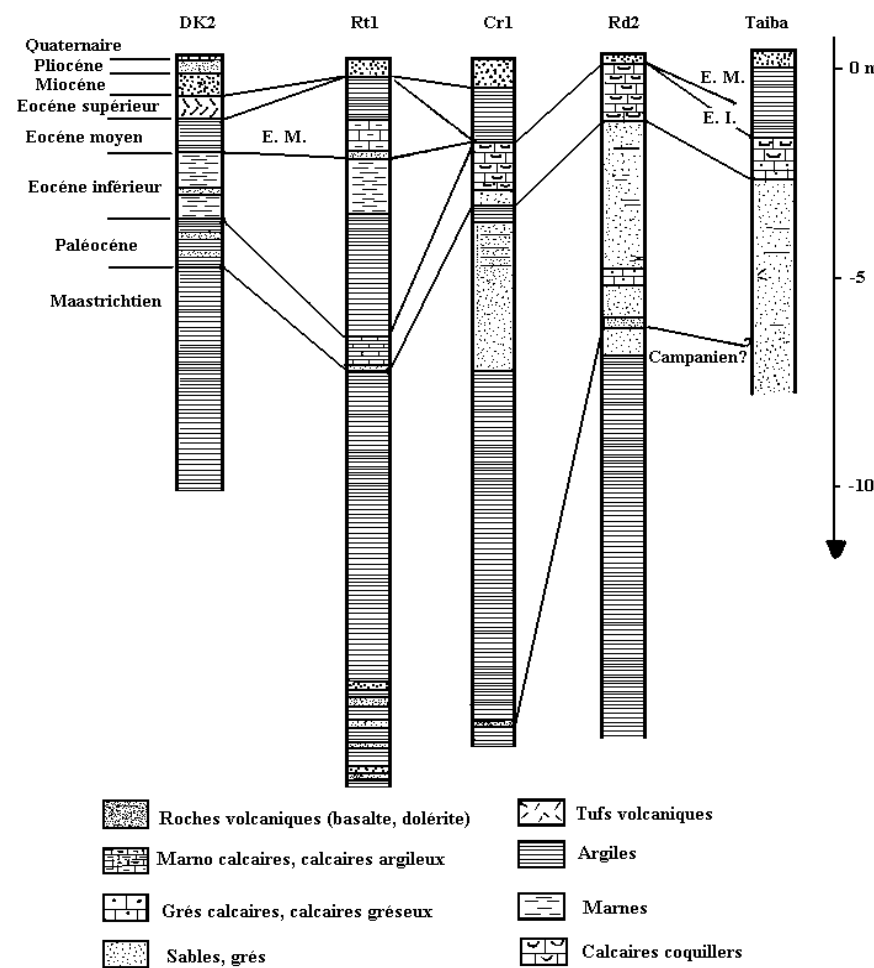

Fig. 2 Lithostratigraphic correlations from the logs of deep boreholes carried out in the Dakar region by Petrosen [13]

https://doi.org/10.30799/jespr.216.22080101

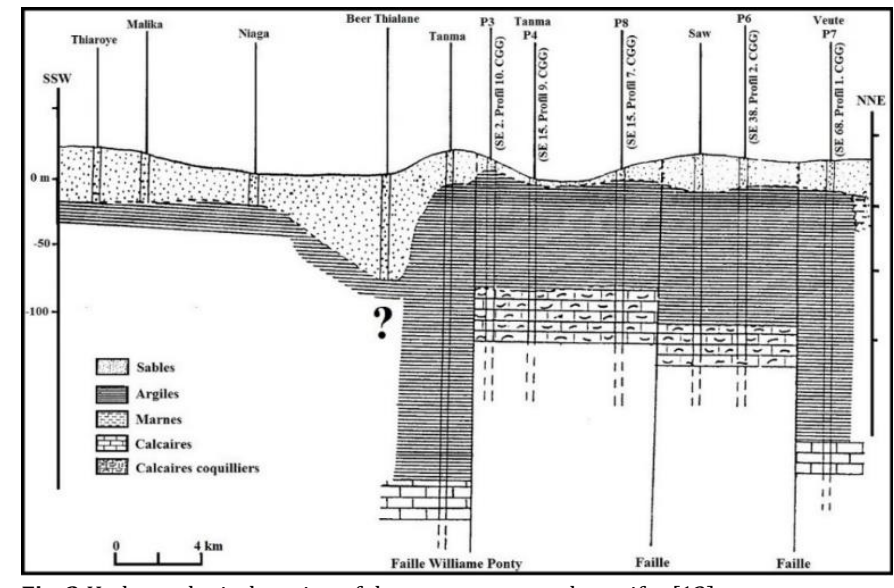

Fig. 3 Hydrogeological section of the quaternary sands aquifer [12]

The piezometry in the study area also shows variations over the year and from one year to the next depending on the intensity of rainfall and the operating conditions of the water table. The piezometric maps in the sector of lake Mbeubeuss drawn up from data from March 2003, July 2002 and July 1998, show a direction of global flow towards the ocean, inland lakes (Mbeubeuss and Retba) and piezometric depressions (Figs. 4-6).

This flow is conditioned by the rise of the Eocene marl-limestone substratum to the south-east, a consequence of the tectonic movements at the origin of the horsts of Dakar and Ndiass and the graben of RufisqueBargny [11].

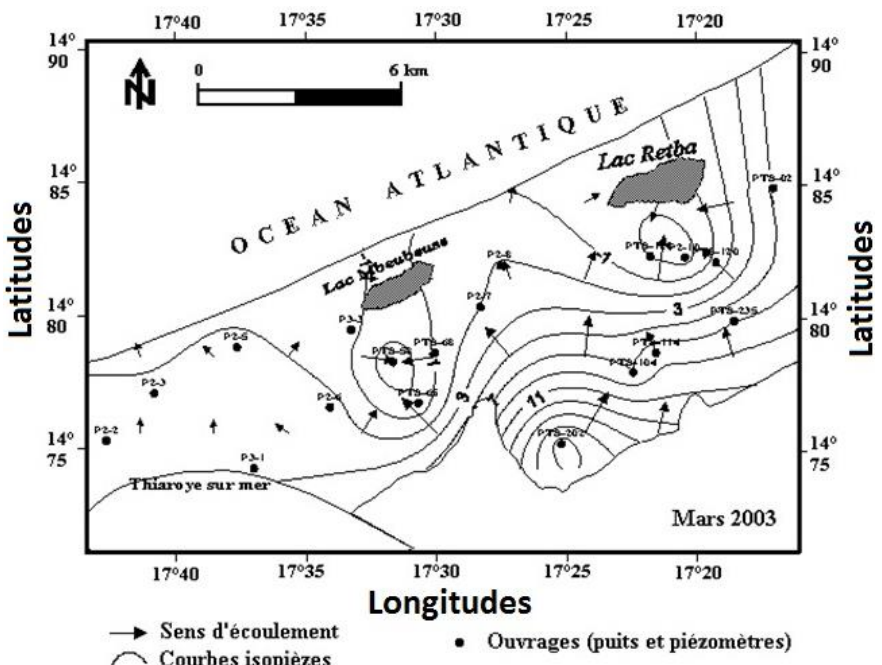

Fig. 4 Piezometric map in the area of lake Mbeubeuss [5]

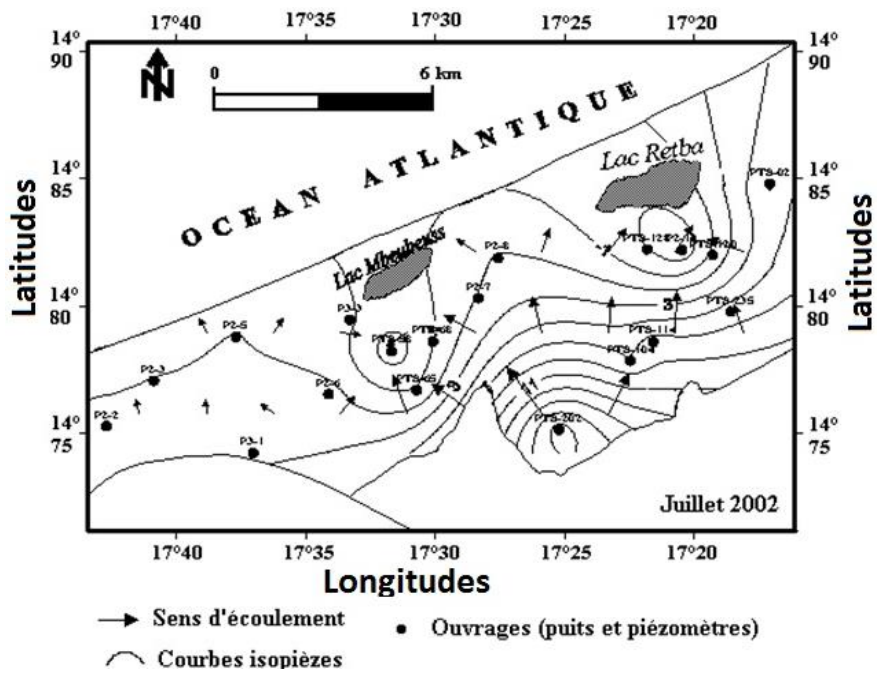

Fig. 5 Piezometric map in the area of lake Mbeubeuss [5]

The distribution of the piezometric levels in the sector of Lake Mbeubeuss is characterized by the presence of a recharge area of the quaternary sands aquifer (or piezometric dome) at the well (Pts-202). We also note the presence of two drainage areas of the quaternary sand table 
(or piezometric depressions), one around the wells (Pts-58, Pts-65 and Pts-68) in the area of Lake Mbeubeuss and the other around the water points (Pts-120, Pts-128 and P2-10) in the Lake Retba area. The hydraulic gradients are generally low and hardly exceed $1 \%$ in the studied sector [5].

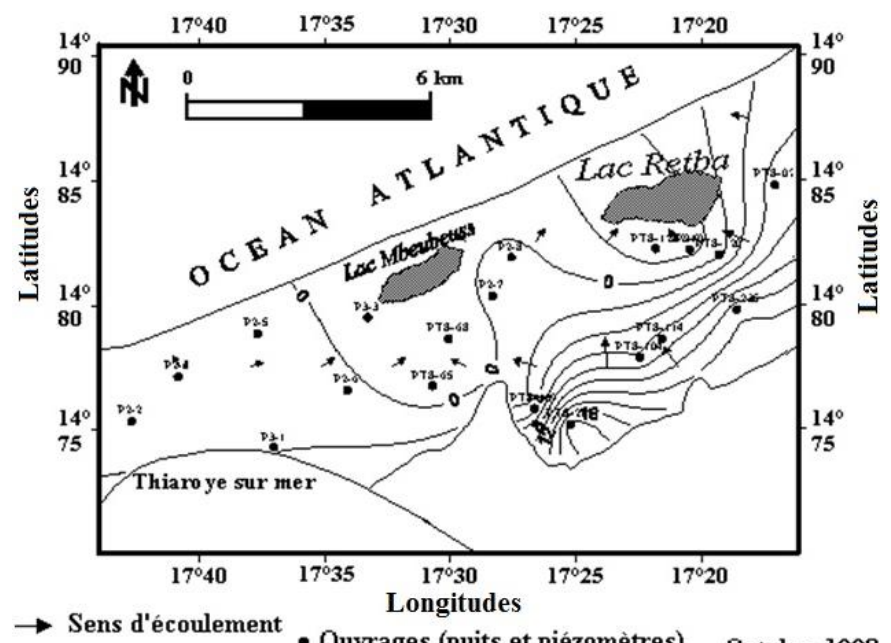

Courbes isopièzes

Fig. 6 Piezometric map in the area of Lake Mbeubeuss [5]

\subsection{Collection and Chemical Analysis of Groundwater}

Many hydraulic structures (boreholes, piezometers and villages wells) exploiting the quaternary sands aquifer in the Mbeubeuss lake sector have been carried out following the various study programs concerning the supply of drinking water, in parallel with the increase of population of the Dakar region. These hydraulic structures are placed under the responsibility of the Water Resources Management and Planning Directorate (DGPRE) of the Senegalese Ministry of Hydraulics (Boreholes and piezometers) and market gardeners (traditional wells). For this study, samples were taken from around thirty hydraulic structures in the Mbeubeuss Lake sector were taken on July 16 and 17, 1998 for the first campaign, from July 22 to 24, 2002 for the second campaign and from March 5 to 7, 2003 for the last campaign.

The geographical location of the hydraulic structures (piezometers and village wells) sampled during the various sampling campaigns is shown in Fig. 7. In the field, the static levels of the water table and the heights of the copings in relation to the ground of the various hydraulic structures (piezometers and village wells) were measured using a light and sound probe. In addition to the piezometric monitoring, physical parameters (temperature, $\mathrm{pH}$ and electrical conductivity) were measured in-situ and water samples taken in well-sealed polyethylene bottles for chemical analyzes in the Hydrology laboratory and Hydrochemistry of the Department of Geology of the Faculty of Sciences and Techniques of the University Cheikh Anta Diop of Dakar in Senegal.

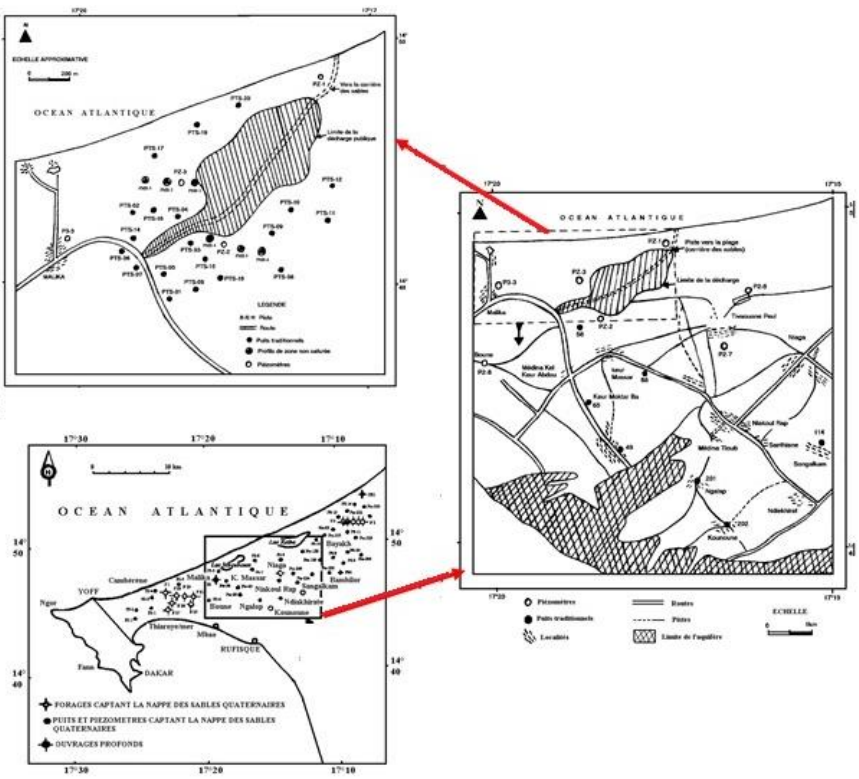

Fig. 7 Location of the hydraulic structures sampled [5] https://doi.org/10.30799/jespr.216.22080101
In the laboratory, chemical analyzes of chloride ions $\left(\mathrm{Cl}^{-}\right)$, sulphates $\left(\mathrm{SO}_{4}{ }^{2-}\right)$, nitrates $\left(\mathrm{NO}_{3}^{-}\right)$, sodium $\left(\mathrm{Na}^{+}\right)$, magnesium $\left(\mathrm{Mg}^{2+}\right)$ and calcium $\left(\mathrm{Ca}^{2+}\right)$ were carried out by ion chromatography (Dionex DX 120$)$, those of carbonate $\left(\mathrm{CO}_{3}{ }^{2-}\right)$ and bicarbonate $\left(\mathrm{HCO}_{3}^{-}\right)$ions by titrimetry and those of phosphate ions $\left(\mathrm{PO}_{4}^{3-}\right)$ by flame chromatography.

A systematic check of the relative errors $(|\varepsilon|)$ on the ionic balances of the results of the chemical analyzes was carried out for all the water points analyzed in the laboratory [14]. The values of the relative errors on the ionic balances are less than or equal to $10 \%$, which testifies to the good quality of the chemical analyzes, and these can be treated without restriction using the hydrochemical data processing software such as diagram software developed by Roland Smiler from the hydrogeology laboratory of the University of Avignon and Microsoft Excel.

\section{Results and Discussion}

\subsection{Physico-Chemical Characteristics of Groundwater}

The groundwater temperature values are between $26.84{ }^{\circ} \mathrm{C}$ (Pts-202) and $33.50{ }^{\circ} \mathrm{C}$ (Pts-17) for the July 1998 campaign; between $27.60^{\circ} \mathrm{C}$ (Pts58 ) and $31.40^{\circ} \mathrm{C}$ (Pts-04) for the July 2002 campaign and between 22.50 ${ }^{\circ} \mathrm{C}$ (Pts-10) and $29.20{ }^{\circ} \mathrm{C}$ (P2-2) for the March 2003 campaign. These values of groundwater temperatures are very similar of ambient atmospheric temperatures. These would suggest the opening of the aquifer system, hence its vulnerability to surface pollution. The groundwater $\mathrm{pH}$ values are between 5.03 (Pts-65) and 8.57 (Pts-20) for the July 1998 campaign, between 3.18 (Pts-03) and 9.82 (Pts- 68) for the July 2002 campaign and between 4.39 (Pts-03) and 9.96 (Pts-68) for the March 2003 campaign. These recorded $\mathrm{pH}$ values would indicate that the groundwater is acidic to slightly basic and that alkalinity is essentially controlled by bicarbonates [15].

Groundwater electrical conductivity values vary from $218 \mu \mathrm{S} / \mathrm{cm}$ (P33) to $9990 \mu \mathrm{S} / \mathrm{cm}$ (Pts-14) for the July 1998 campaign, from $215 \mu \mathrm{S} / \mathrm{cm}$ (P3-3) to $4720 \mu \mathrm{S} / \mathrm{cm}$ (Pts-03) for the July 2002 campaign and from 235 $\mu \mathrm{S} / \mathrm{cm}$ (P3-3) to $5560 \mu \mathrm{S} / \mathrm{cm}$ (Pts-03) for the March 2003 campaign. These values of electrical conductivity of groundwater are in average less than $2000 \mu \mathrm{S} / \mathrm{cm}$ at the level of hydraulic structures further away from the public discharge and greater than $2000 \mu \mathrm{S} / \mathrm{cm}$ at the level of hydraulic structures closer to the Mbeubeuss discharge. These would suggest a significant contribution of the public landfill to the mineralization of groundwater in the studied sector. The data from the chemical analyzes of groundwater from July 1998, July 2002 and March 2003 are plotted on Piper triangular diagrams to determine the chemical families and facies of the waters in the Mbeubeuss lake sector (Fig. 8).

In detail, the chemical evolution of groundwater during the various sampling campaigns is as follows:

For the July 1998 campaign, the triangular diagram of anions shows a predominance of points evolving towards the chlorinated pole $(76 \%)$ and $24 \%$ of the water points are shifted towards the sulphated pole and the center of the triangle, where no predominance of one anion over the other is noted. However, in the triangular diagram of cations, the water points are divided into three groups: the first evolving towards the sodium pole (39\%), the second towards the calcium pole (18\%) and the third towards the central zone. mixed non-predominance of different cations (43\%). In the quadrangular diagram, the waters are mainly divided into two chemical families: chlorinated sulphated sodium and potassium water and chlorinated sulphated calcium and magnesian water.

On the other hand for the campaign of July 2002, in the triangular diagram of the anions, we still distinguish three groups of points: the first near the chlorinated pole $(72 \%)$, the second with evolution towards the sulphated pole (8\%) and the third to the central mixed zone (20\%). In the triangular cation diagram, there are always three groups of water points: the first evolving towards the sodium pole (36\%), the second towards the calcium pole $(8 \%)$ and the third towards the mixed central zone of nonpredominance of the different cations (56\%) and in the quadrangular diagram, we can mainly distinguish two chemical families: chlorinated sulphated sodium and potassium waters; and chlorinated sulphated calcium and magnesian waters.

For the March 2003 campaign, in the triangular diagram of anions, the water points are divided into four groups: the first near the chlorinated pole $(73 \%)$, the second group near the sulphated pole $(9 \%)$, the third towards the bicarbonate pole $(9 \%)$ and last group at the center of the anion triangle (9\%). In the triangular diagram of cations, there are always three groups of water point: the first with evolution towards the sodium pole $(39 \%)$, the second towards the calcium pole $(4 \%)$ and the third towards the zone where no cation does not dominate the other (57\%). However, in the quadrangular diagram, the waters are mainly divided into two chemical families: sulphated sodium and potassium chlorinated waters and sulphated calcium and magnesian chlorinated waters. 
The water points, which were generally divided into two chemical facies (sodium chloride and calcium sulphate chloride) in July 1998 and July 2002, are divided into three chemical facies (sodium chloride; calcium sulphate chloride and calcium bicarbonate) for the March 2003 campaign. During the last campaign, this separation is the result of an increase in the bicarbonate and calcium contents and a decrease in the sodium contents at the level of the piezometers (P2-7 and P2-8).

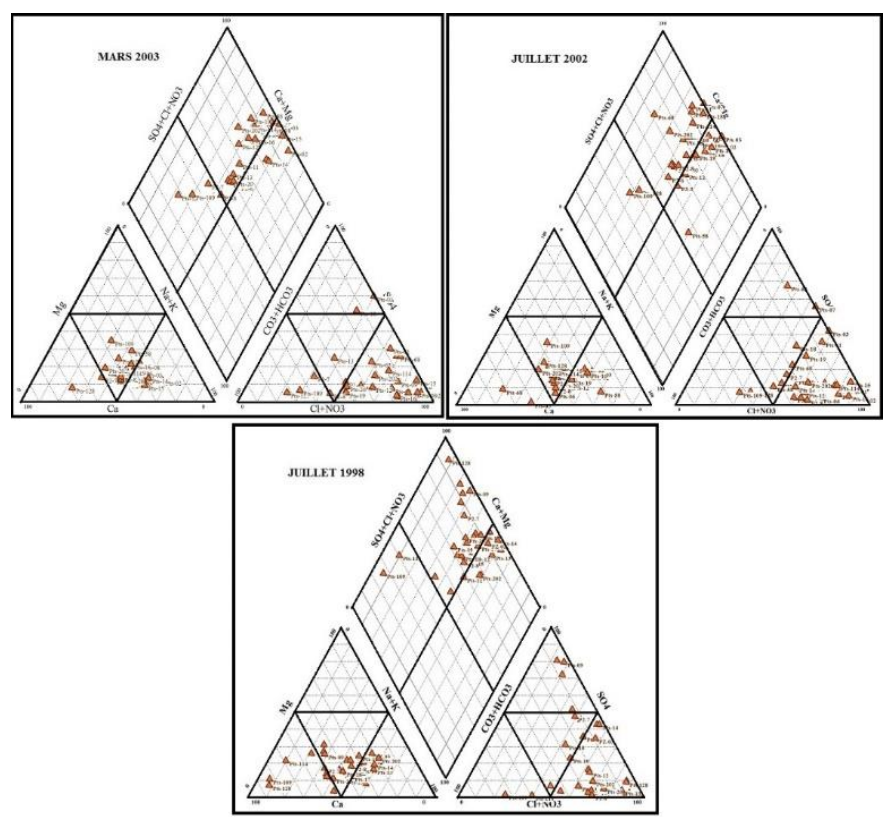

Fig. 8 Piper triangular diagram of groundwater [5]

\subsection{Origin and Process of Groundwater Mineralization}

The natural chemical facies of groundwater responds to a determinism partly due to the lithological nature of aquifers and surface soils crossed by water. The lithological descriptions of the aquifer show an almost exclusively sandy matrix. In this geological context, the origin of the mineralization of the water in this aquifer in the Mbeubeuss Lake sector is not only linked to the lithology of the aquifer. It may probably be due to meteoric inputs (rain and evaporation), to the acquisition of chemical elements by dissolution or alteration of clay minerals present in the reservoir and to surface inputs by percolation in the unsaturated zone during infiltration. Rainwater (leaching of soil and leaching of organic matter from household garbage) and basic exchange processes between groundwater and the aquifer matrix.

Taking into account the concentration of major ions in groundwater, the concentrations observed in July 1998, July 2002 and March 2003 are very high for an aquifer matrix made up of sandy to sandy-clay materials and fed mainly by rainwater (Table 1 ).

Table 1 Average chemical composition of rainwater [16] and of the quaternary sands aquifer at Mbeubeuss [5]

\begin{tabular}{llllll}
\hline $\begin{array}{l}\text { Major chemical } \\
\text { elements }\end{array}$ & Stations & $\begin{array}{l}\text { In rainwaters } \\
(\mathrm{mg} / \mathrm{L})\end{array}$ & \multicolumn{3}{l}{$\begin{array}{l}\text { In barehold Thiaroye at } \\
\text { Mbeubeuss sector }\end{array}$} \\
\cline { 4 - 6 } & & & July 1998 & July 2002 & March 2003 \\
\hline Sodium $\left(\mathrm{Na}^{+}\right)$ & Dakar & 3.36 & 166.42 & 97.37 & 109.90 \\
Potassium $\left(\mathrm{K}^{+}\right)$ & Dakar & 0.57 & 13.88 & 9.19 & 11.76 \\
Calcium $\left(\mathrm{Ca}^{2+}\right)$ & Dakar & 1.7 & 103.41 & 69.89 & 68.36 \\
Magnesium $\left(\mathrm{Mg}^{2+}\right)$ & Dakar & 0.39 & 39.29 & 18.9 & 21.71 \\
Sulphates $\left(\mathrm{SO}_{4}^{2-}\right)$ & Dakar & 2.42 & 319.22 & 131.86 & 139.80 \\
Nitrates $\left(\mathrm{NO}_{3}{ }^{-}\right)$ & Dakar & 0.07 & 52.92 & 65.85 & 63.47 \\
$\begin{array}{l}\text { Bicarbonates } \\
\left(\mathrm{HCO}_{3}^{-}\right)\end{array}$ & Saint & 2.21 & 99.21 & 77.8 & 76.15 \\
\left.${\text { Chlorinates }\left(\mathrm{Cl}^{-}\right)}\right)$ & Louis & & & & \\
& Saint & 2.26 & 268.18 & 179.15 & 153.99 \\
\hline
\end{tabular}

These results imply an external source of mineralization of the Quaternary sands table by rainwater during their infiltration, hence the interest of studying the saturation indices with respect to the different mineral phases and the relationship between the concentrations of the various major elements and the chloride ions.

\subsection{Saturation Indices (SI) with Respect to the Different Mineral Phases}

The saturation indices (SI) of the waters in relation to the mineral phases (anhydrite $\left(\mathrm{CaSO}_{4}\right)$, aragonite $\left(\mathrm{CaCO}_{3}\right)$, calcite $\left(\mathrm{CaCO}_{3}\right)$, dolomite https://doi.org/10.30799/jespr.216.22080101
$\left(\mathrm{CaMg}\left(\mathrm{CO}_{3}\right)_{2}\right)$, magnesite $\left(\mathrm{MgCO}_{3}\right)$ and gypsum $\left(\mathrm{CaSO}_{4}, \mathrm{H}_{2} \mathrm{O}\right)$, were calculated for the three sampling campaigns (July 1998, July 2002 and March 2003) from the WATEQ program $[17,18]$.

Fig. 9 shows the relationship between the saturation indices and the TDS, allowing the determination of the saturation or equilibrium state formed by a band between saturation indices -1 and 1 . The area above this band characterizes the oversaturation state and the under saturation state is below this band [19].

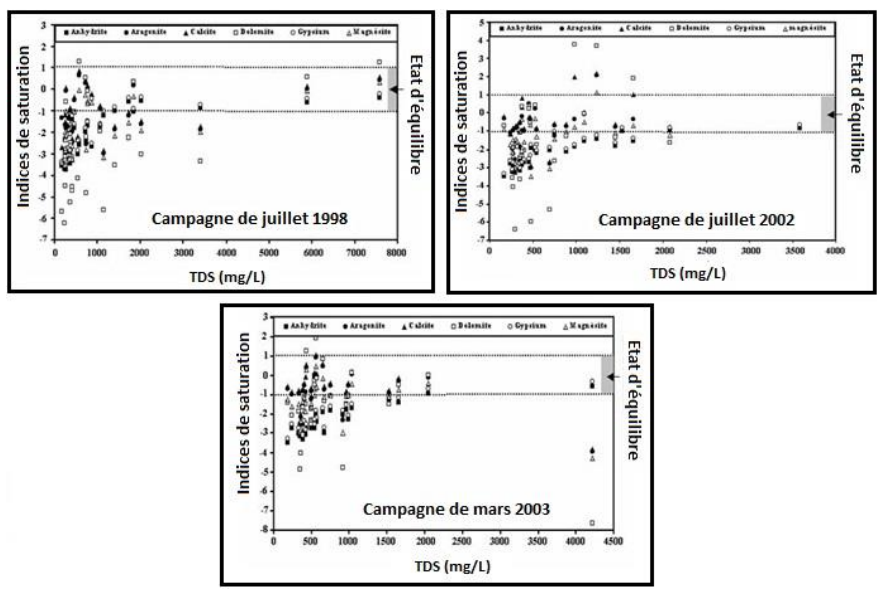

Fig. 9 Saturation indices (SI) as a function of groundwater TDS [5]

\subsection{Binary Dilution-Concentration Diagrams of Major Chemical Elements}

The values of the saturation indices of anhydrite $\left(\mathrm{CaSO}_{4}\right)$ and gypsum $\left(\mathrm{CaSO}_{4} \mathrm{H}_{2} \mathrm{O}\right)$ ) show that the groundwater is under-saturated to oversaturated with respect to anhydrite and gypsum for the campaigns of July 1998, July 2002 and March 2003.

For the saturation index values for aragonite $\left(\mathrm{CaCO}_{3}\right)$ and calcite $\left(\mathrm{CaCO}_{3}\right)$, the groundwater shows that it is under-saturated to saturated with respect to aragonite and calcite for the campaigns of July 1998 and March 2003 and under-saturated to supersaturated for the campaign of July 2002. For the saturation towards dolomite $\left(\mathrm{CaMg}\left(\mathrm{CO}_{3}\right)_{2}\right)$, the groundwater is under-saturated, in equilibrium and supersaturated towards dolomite for the campaigns of July 1998, July 2002 and March 2003. For the sub-saturation state, the mineral phases of these elements, if they would exist in the aquifer matrix, could be easily solubilized in contact with groundwater.

The saturation state of the groundwater with respect to the mineral phases indicates that the groundwater is in thermodynamic equilibrium with the different solid phases of these minerals. The state of supersaturation with respect to the mineral phases indicates that if these mineral phases exist, the groundwater can allow a precipitation of these mineral phases. It should be noted, however, that the solubility of a mineral can be decreased if another source of input of one of the dissociation ions is involved; this would increase the value of the SI saturation index [20]. However, $\mathrm{HCO}_{3}{ }^{-}$ions can be produced in the groundwater via $\mathrm{CO}_{2}$ dissolved in water.

In order to discuss the origin and mineralization processes of the Quaternary sand aquifer waters in the Lake Mbeubeuss area, we studied the relationships between the major chemical elements and the chloride ion. The latter is a conservative element that does not participate in water/rock interactions and characterizes the origin of groundwater mineralization constituting a mixing tracer [21, 22].

The data from the chemical analyses of groundwater from the campaigns of July 1998, July 2002 and March 2003, are reported on the binary diagrams of ionic contents in relation to chlorides with the aim of highlighting the surface contributions to the groundwater table. The chemical data on rainwater come from the work of Travi et al. [16] and concern the averages of July and August 1981 from the synoptic stations of Dakar-Yoff and Saint-Louis.

The arrangement of the different water points in relation to the theoretical rainwater-sea water (freshwater-salt water) mixing line can be of great help in identifying other phenomena that are appended to the mixing processes. The groundwater of the various hydraulics wells in the Lake Mbeubeuss area, in general, shows an enrichment of sulphate, bicarbonate and calcium ions and a dispersion of points around the theoretical rainwater-sea water mixing line for sodium, potassium and magnesium ions. The major reactions known to be responsible for enrichment or depletion of major elements in groundwater are: (a) exchange or substitution of base $\mathrm{Ca}^{2+} \leftrightarrow \mathrm{Mg}^{2+}$ due to water-rock interaction; (b) $\mathrm{Na}^{+} \leftrightarrow \mathrm{Ca}^{2+}$ or $\mathrm{Na}^{+} \leftrightarrow \mathrm{Mg}^{2+}$ by base-exchange and (c) sulphate reduction [21]. 
The relationship between bicarbonate and chloride contents in groundwater shows that all the water points in the July 1998, 2002 and March 2003 campaigns are above the theoretical rainwater-seawater mixing line (Fig. 10).
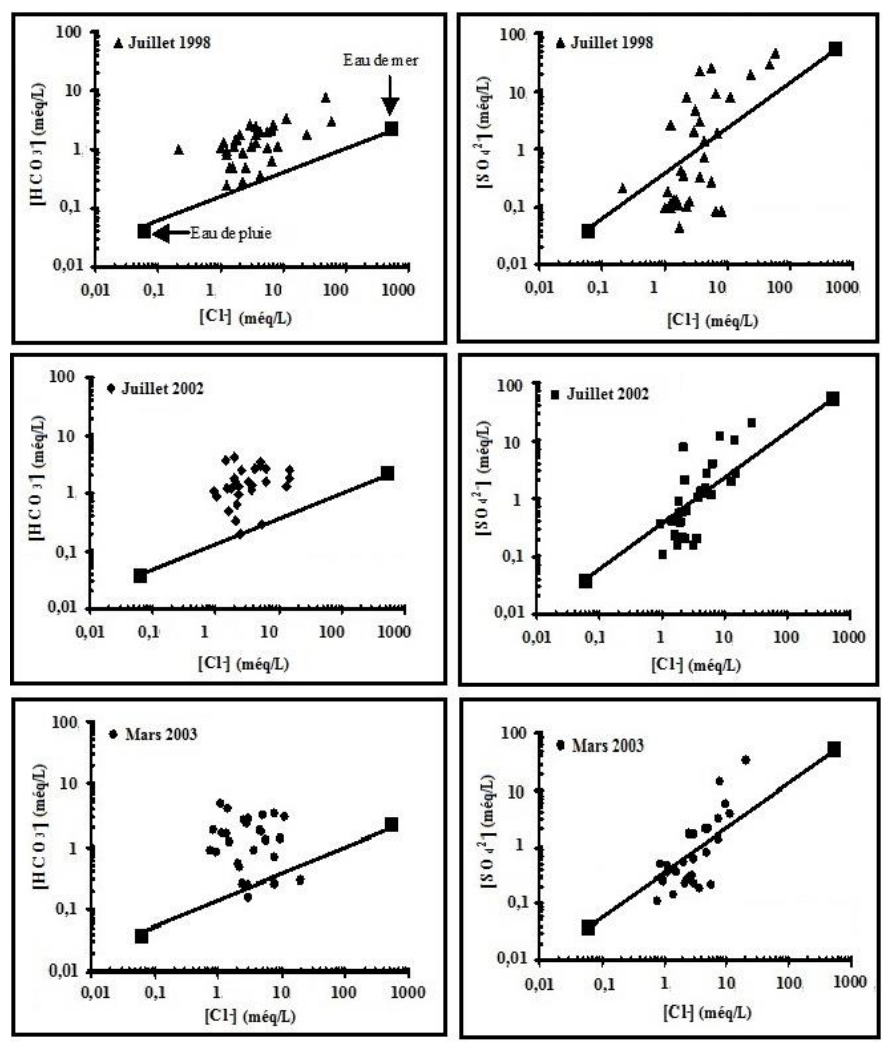

Fig. 10 Relationship between $\mathrm{SO}_{4}{ }^{2-}$ and $\mathrm{HCO}_{3}$ content with $\mathrm{Cl}$. in groundwater, rainwater and seawater (July 1998, 2002 and March 2003) [5]

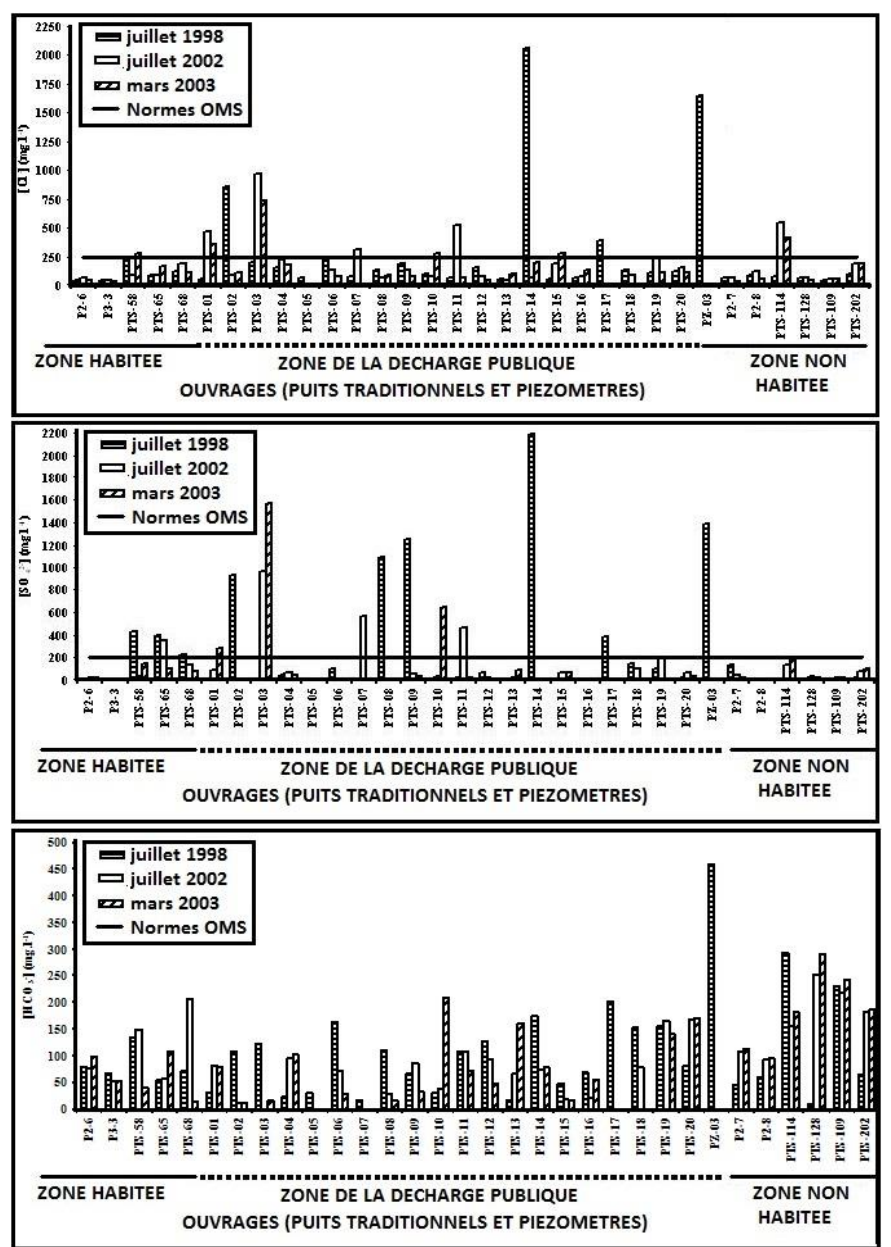

Fig. 11 Comparison of chloride, sulphate and bicarbonate levels in groundwater in the Thiaroye/Lake Mbeubeuss sector to WHO standards [5]

https://doi.org/10.30799/jespr.216.22080101
Thus, there would have been an enrichment of bicarbonates in the groundwater. This bicarbonate enrichment in the study area could have several origins: the dissolution of atmospheric $\mathrm{CO}_{2}$ and soils and organic matter from the decomposition of household waste from the public landfill (Fig. 11).

These waters have bicarbonate ion concentrations higher than those of the theoretical rainwater-sea water mixing line. One could also add the very likely influence of the carbonate bottom of the aquifer on the bicarbonate production in the Lake Mbeubeuss area.

For the dilution-concentration diagram showing the relationship between $\mathrm{Cl}^{-}$and $\mathrm{SO}_{4}{ }^{2-}$ in groundwater, Fig. 10 shows that several water points are above the theoretical rainwater-seawater mixing line with a few points below this line. The water points located below the theoretical mixing line reflect dilution and oxidation-reduction phenomena contributing to a decrease in sulphate content in the groundwater. However, the samples located above the theoretical rainwater-sea water mixing line show that there would be an addition of sulphates and present molar ratios $\mathrm{SO}_{4}{ }^{2-} / \mathrm{Cl}^{-}$higher than that of sea water. The enrichment of these samples in sulphates could result either from the unsaturated zone of the quaternary sands aquifer by leaching of the products of the decomposition of domestic waste during the percolation of rainwater to the water table, or from the leaching of marine aerosols and sea spray which contain high levels of sulphates compared to chlorides. In fact, domestic waste produces large quantities of sulphates and rainwater from the coastal regions of Senegal shows relatively low $\mathrm{SO}_{4}{ }^{2-} / \mathrm{Cl}^{-}$ratios, but these remain clearly high compared to that of seawater [16].
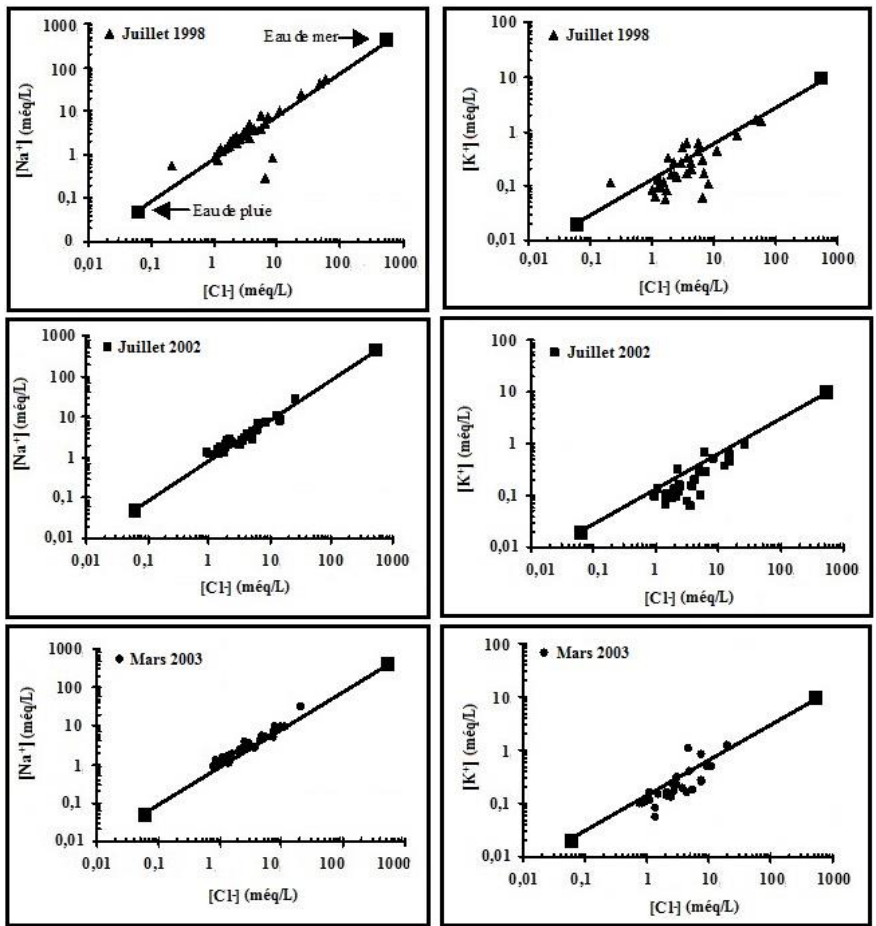

Fig. 12 Relationship between $\mathrm{Na}^{+}, \mathrm{K}^{+}$and $\mathrm{Cl}^{-}$content in groundwater, rainwater and seawater (July 1998, 2002 and March 2003) [5]

Fig. 12 shows the evolution of sodium, potassium and chloride levels in groundwater and seawater. Analysis of the graph $\mathrm{Cl}^{-}$versus $\mathrm{Na}^{+}$shows that the water points are well aligned along the theoretical line of freshwatersea water mixing for the campaigns of July 1998, July 2002 and March 2003. These points show that the $\mathrm{Cl}^{-}$and $\mathrm{Na}^{+}$ions are well correlated and have a common origin. This means that these two ions should be in equilibrium, but as their ratio shows, this is not always the case. The deficit of $\mathrm{Na}^{+}$ions in some water points can be explained by a phenomenon of ion exchange between water and aquifer resulting in an adsorption of $\mathrm{Na}^{+}$and a release of $\mathrm{Ca}^{2+}$. The behaviour of water points from the vicinity of the rainwater pole to the vicinity of the seawater pole shows a succession of concentration and dilution phenomena. However, for the July 1998 campaign, three water points deviated from the cloud points, including one above the theoretical mixing line and two others below the line.

The position of the two water points below the straight line could be related to the phenomena of dilution by rainwater, whereas that of the point located above the rainwater pole could be explained by an enrichment of this point in $\mathrm{Na}^{+}$, either by substitution or basic exchange phenomena between groundwater and the geological formation constituting the aquifer. An indirect influence of sea water, whose mineralization is due to the leaching of aerosols and sea spray by 
rainwater, can also be envisaged. This enrichment could also be due to an influence of the public landfill on the mineralization of groundwater following the leaching of household waste during the infiltration of rainwaters (Fig. 13).

The relationship between the $\mathrm{K}^{+}$and $\mathrm{Cl}^{-}$ion contents shows that the water samples are located on either side and along the theoretical rainwater-seawater mixing line. The water points that are located below the theoretical dilution-concentration line suggest phenomena of dilution by rainwater or substitution and/or base exchange between the alkalis in the groundwater and the alkaline earths in the aquifer matrix. The water points that are aligned on the theoretical mixing line show a good correlation between $\mathrm{K}^{+}$and $\mathrm{Cl}^{-}$ions (the most probable origin of $\mathrm{K}^{+}$would be rather marine) but also an increase in the potassium ion content.

Finally, the samples above the theoretical rainwater-seawater mixing line would show a slight increase in potassium content. In the Lake Mbeubeuss sector, potassium ion enrichment could be linked to a contribution due to the leaching of household waste during the infiltration of rainwater into the groundwater table. The study of the unsaturated zone in the immediate vicinity of the landfill showed high levels of potassium ions in the surface horizons. There is also a contribution due to the dissolution of clay minerals contained in the sandy sediments.
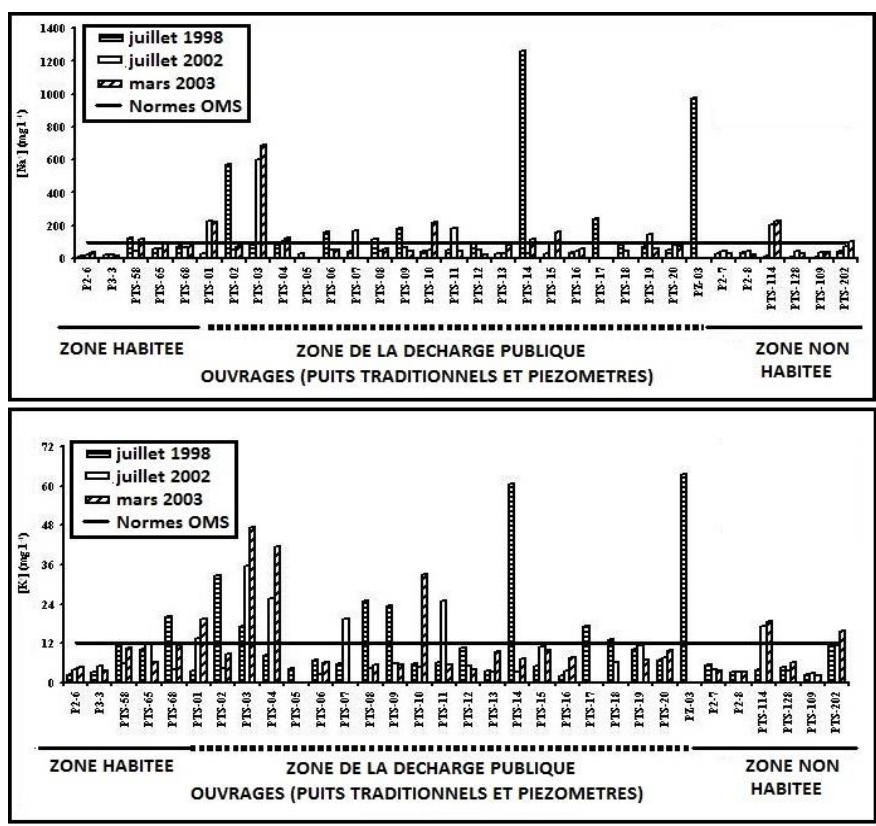

Fig. 13 Comparison of sodium and potassium levels in groundwater in the Thiaroye/Lake Mbeubeuss area to WHO standards [5]
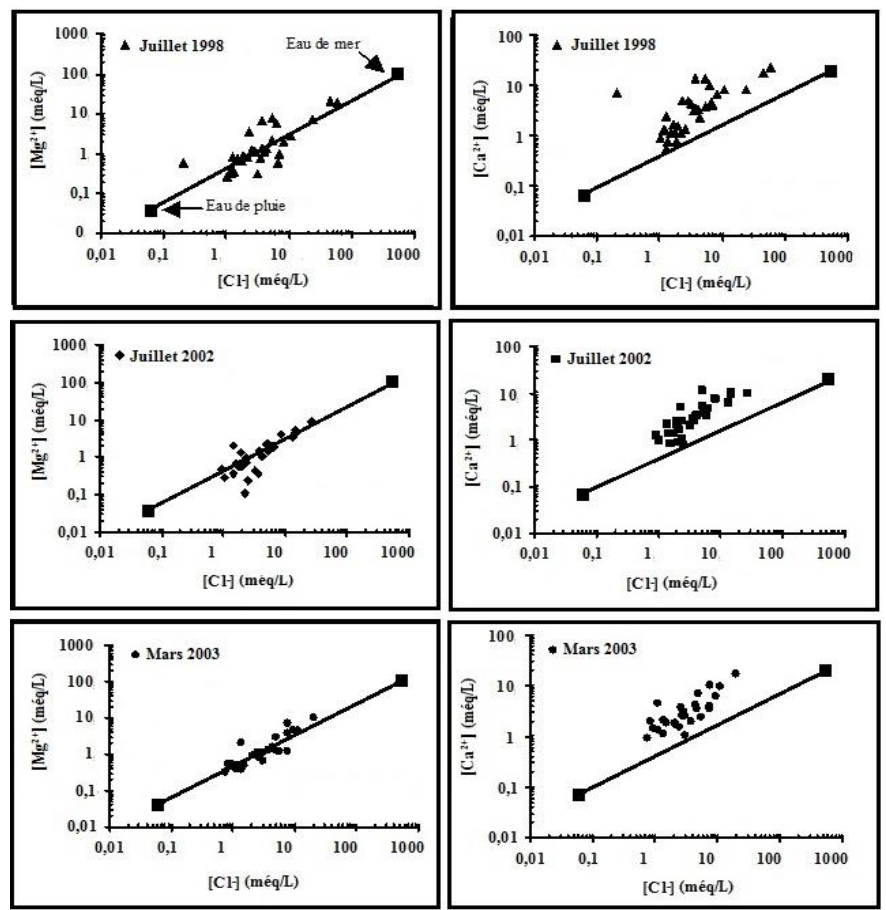

Fig. 14 Relationship between $\mathrm{Ca}^{2+}, \mathrm{Mg}^{2+}$ and $\mathrm{Cl}^{-}$content of groundwater and water of rain and sea (July 1998, 2002 and March 2003) [5] https://doi.org/10.30799/jespr.216.22080101
For magnesium, the graph $\mathrm{Cl}^{-}$versus $\mathrm{Mg}^{2+}$ shows that the water points are distributed near the theoretical mixing line between rainwater and seawater for the July 1998, July 2002 and March 2003 campaigns. The water points along the line have the same $\mathrm{Mg}^{2+}$ concentrations as the dilution water, those above the line have higher concentrations and those below have lower concentrations (Fig. 14).

The water points along the dilution-concentration line tend to spread, likely reflecting mineralization from aerosol and sea spray leaching during rainwater infiltration. For the first group, it would appear that the chloride and magnesium contents of these water points and fresh water are approximately the same. So there would be a dilution phenomenon at this level. Contrary to this first group, we note a second group of points located above the theoretical mixing line showing a slight enrichment in magnesium. This slight magnesium enrichment may be due to the leaching of marine aerosols and sea spray and to the phenomena of base-exchange $\left(\mathrm{Na}^{+} \leftrightarrow \mathrm{Mg}^{2+}\right)$ between the water table and the aquifer matrix and the dissolution of clay minerals present in the aquifer matrix.

Magnesium ion enrichment can also be linked to the leaching of household waste from the public dump during percolation to the rainwater table. Indeed, the study of the unsaturated zone near the landfill site also showed very high levels of magnesium ions from the surface to the groundwater table and it only takes a rain event that can cause infiltration to carry the salts to the groundwater table (Fig. 15).

The relationship between $\mathrm{Ca}^{2+}$ and $\mathrm{Cl}^{-}$ion contents for the campaigns of July 1998, July 2002 and March 2003 shows that almost all the water points are located above the theoretical rainwater-seawater mixing line.

The position of the points shows a tendency to vertical shift and spread with respect to the theoretical mixing line. The vertical grouping of the points above the dilution line suggest an additional $\mathrm{Ca}^{2+}$ input compared to the theoretical mixing water contents. The spreading of points close to the pole of the seawater indicate a phenomena of concentration by evaporation or mixing of the water [6].
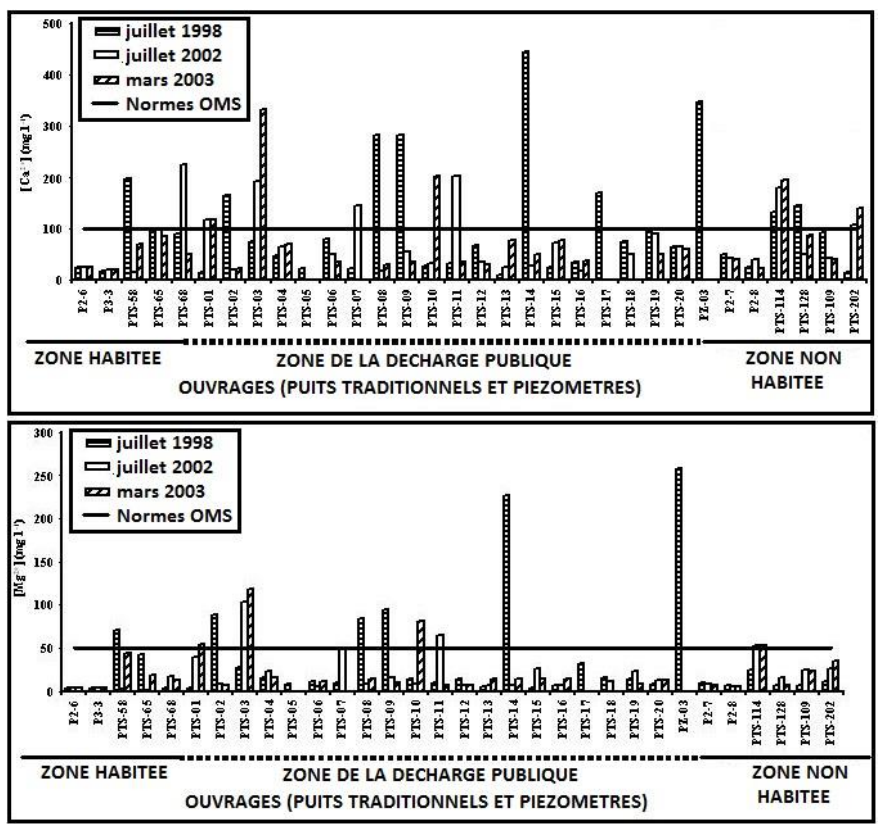

Fig. 15 Comparison of magnesium and calcium levels in groundwater in the Thiaroye/Lake Mbeubeuss sector to WHO standards [5]

The additional $\mathrm{Ca}^{2+}$ input could be attributed to several main factors: to the leaching of household waste dumped in the Mbeubeuss Lake sector by rainwater; to cationic exchanges $\left(\mathrm{Ca}^{2+} \leftrightarrow \mathrm{Mg}^{2+}\right)$ due to water-rock interaction; to the basic exchange phenomena $\left(2 \mathrm{Na}^{+} \leftrightarrow \mathrm{Ca}^{2+}\right)$ between the water table and the aquifer matrix and to the dissolution of the carbonated substratum that constitutes the bottom of the quaternary sands aquifer. The spreading of the points, some of which are close to the pole of the sea water, indicate a phenomena of concentration by evaporation.

\subsection{Setting in Evidence of the Basis Exchanges}

The basis exchanges that characterize the different aquifer formations and groundwater are setting in evidence by the relationship between $\left[\left(\mathrm{Ca}^{2+}+\mathrm{Mg}^{2+}\right)-\left(\mathrm{HCO}_{3}{ }^{-}+\mathrm{SO}_{4}{ }^{2-}\right)\right]$ and $\left[\left(\mathrm{Na}^{+}+\mathrm{K}^{+}\right)-\mathrm{Cl}^{-}\right]$, shown in Fig. 16. This relationship emphasizes, only on the reactions that can exist between clay minerals and the solution, by getting rid of the ions possibly resulting from other reactions of dissolution of carbonate and evaporate minerals [23].

This Fig. 16 highlights the basis exchanges with clay minerals that affect the waters of the quaternary sand aquifer during the infiltration of 
rainwater and during their stay in the aquifer. In the absence of these reactions, all representative sample points should be located near the point of origin [24].

Four zones are listed as:Zones 1 and 2, where the difference between the ions $\left(\mathrm{Ca}^{2+}\right.$ and $\left.\mathrm{Mg}^{2+}\right)$ and the ions $\left(\mathrm{HCO}_{3}^{-}\right.$and $\left.\mathrm{SO}_{4}{ }^{2-}\right)$ is positive, shows that in these two zones it is the inverse base exchange process that dominates. The negative ratios are due to the retention of alkalis in the clays and the positive ratios to an input of $\mathrm{Na}^{+}$and $\mathrm{K}^{+}$ions from groundwater. However, this contribution remains low due to the high permeability; Zones 3 and 4, where the difference between the ions $\left(\mathrm{Ca}^{2+}\right.$ and $\left.\mathrm{Mg}^{2+}\right)$ and the ions $\left(\mathrm{HCO}_{3}{ }^{-}\right.$and $\left.\mathrm{SO}_{4}{ }^{2-}\right)$ is negative, indicates that the basic exchange process dominates. In these zones, there is a release of $\mathrm{Na}^{+}$ and $\mathrm{K}^{+}$ions and a retention of alkaline earths in the clays.
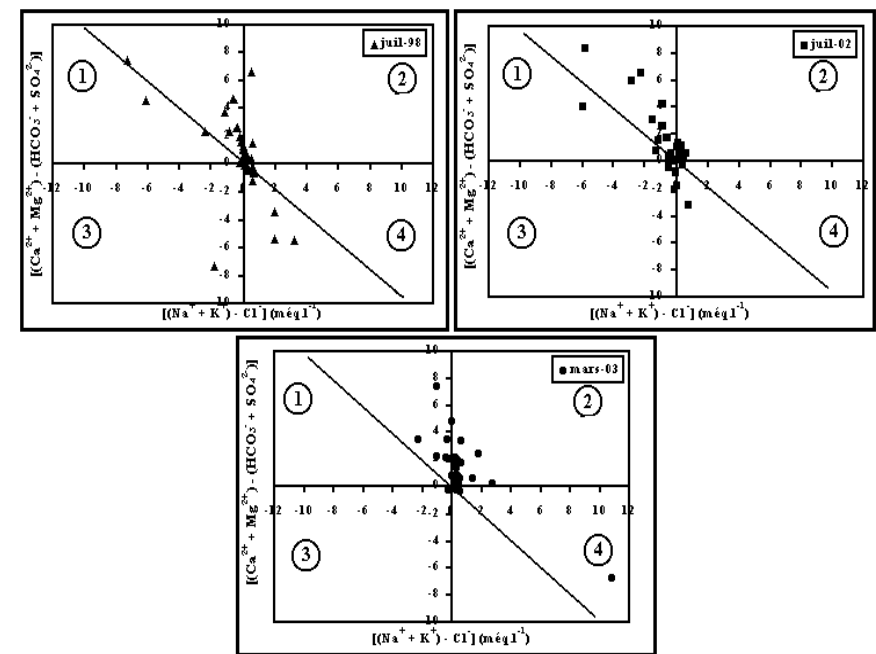

Fig. 16 Binary diagram $\left[\left(\mathrm{Na}^{+}+\mathrm{K}^{+}\right)-\mathrm{Cl}\right]$ vs $\left[\left(\mathrm{Ca}^{2+}+\mathrm{Mg}^{2+}\right)-\left(\mathrm{HCO}_{3}{ }^{-}+\mathrm{SO}_{4}{ }^{2-}\right)\right]$ of groundwater (July 1998, 2002 and March 2003) [5]

\subsection{Setting in Evidence of Minerals Dissolution Phenomena}

The effect of the dissolution of evaporitic and carbonate minerals in aquifers and groundwater can be shown by the relationship between $\left[\left(\mathrm{Ca}^{2+}+\mathrm{Mg}^{2+}\right)\right.$ and $\left(\mathrm{HCO}_{3}{ }^{-}+\mathrm{SO}_{4}{ }^{2-}\right)$ (Fig. 17) $[25,26]$.

This relationship clearly shows that these are the water points of the Quaternary sand aquifer in the sector of Lake Mbeubeuss placed on or close to the slope line 1 known as the theoretical line of dissolution of the different mineral phases present in the aquifer matrix. These dissolution phenomena are present during the three sampling campaigns.
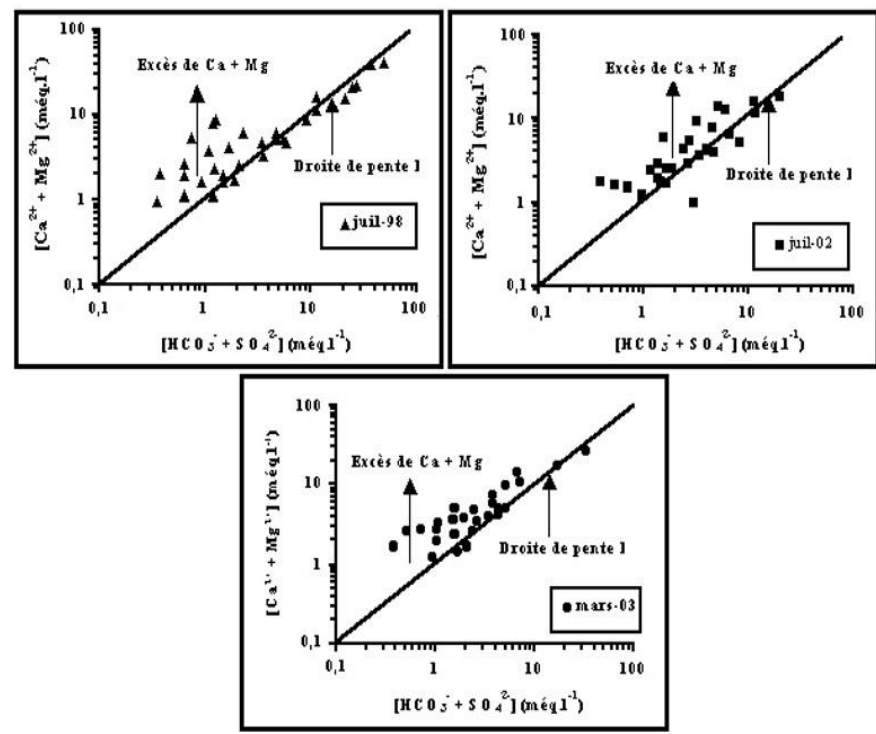

Fig. 17 Binary dissolution diagram $\left[\mathrm{HCO}_{3}{ }^{-}+\mathrm{SO}_{4}{ }^{2-}\right] \mathrm{vs}\left[\mathrm{Ca}^{2+}+\mathrm{Mg}^{2+}\right]$ of groundwater (July 1998, 2002 and March 2003) [5]

\subsection{Diagram of Chadha (1999) [27]}

In order to synthesize the different geochemical processes controlling groundwater mineralization in the Lake Mbeubeuss area, the data from the chemical analyses of groundwater from the July 1998, July 2002 and March 2003 campaigns were plotted on the modified Chadha (1999) diagrams and are distributed as follows (Fig. 18):

https://doi.org/10.30799/jespr.216.22080101

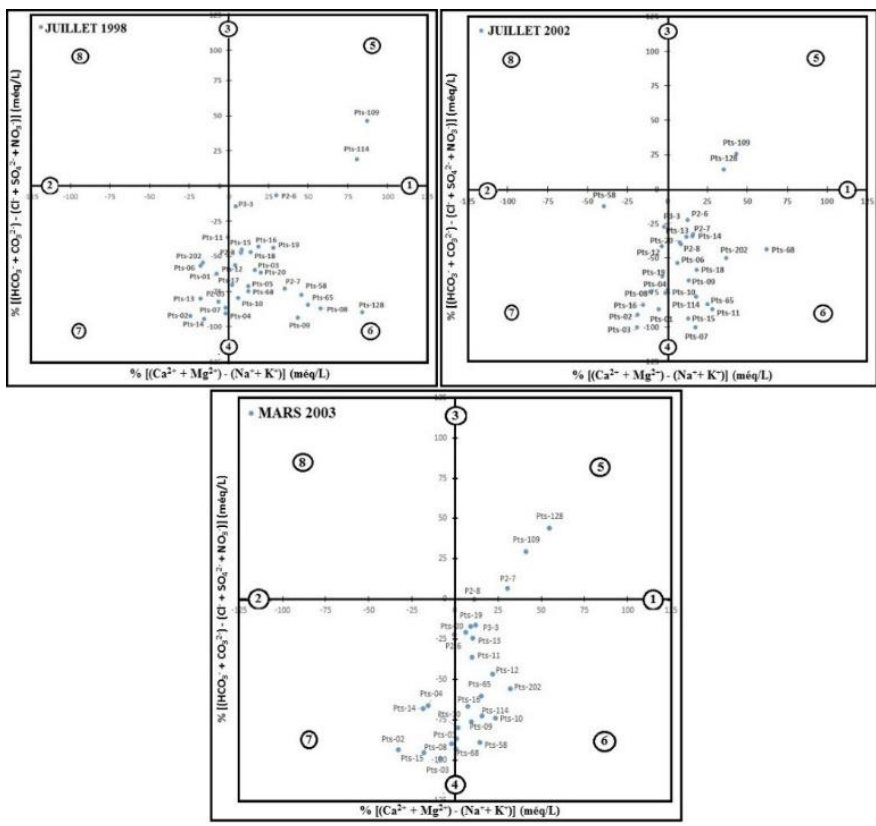

Fig. 18 Representation in Chadha's (1999) modified diagram of the chemical analyses of groundwater from July 1998, July 2002 and March 2003 [5]

- In sub-domain 5, the waters are the calcium bicarbonate type, represented by water points Pts-109 and Pts-114 for the July 1998 campaign; Pts-109 and Pts-128 for the July 2002 campaign and P2-7, P28, Pts-109 and Pts-128 for the March 2003 campaign. These waters would result from the dissolution of carbonate and evaporate minerals present in the aquifer matrix;

- In sub-domain 6, where alkaline earths dominate alkaline metals and strong acid anions dominate weak acid anions; the waters have a permanent hardness and do not favour the precipitation of of sodium carbonate residues in case of irrigation.

These waters, which are the calcium and magnesium chloride type, result either from pollution or from basis inverse exchange processes. The water points are subdivided into two types of water:

- Moderately mineralized waters (TDS $<1000 \mathrm{mg} / \mathrm{L}$ ) with sodium and potassium chloride facies, represented by water points : P3-3, P2-6, Pts65, Pts-68, Pts-03, Pts-05, Pts-10, Pts-12, Pts-15, Pts-16, Pts-17, Pts-18, Pts-19, Pts-20, P2-7 and P2-8 for the July 1998 campaign; P2-6, Pts-06, Pts-09, Pts-13, Pts-14, Pts-15, Pts-18, Pts-20, P2-7, P2-8, Pts-65, Pts-68, Pts-114 and Pts-202 for the July 2002 campaign and P3-3, P2-6, Pts-58, Pts-65, Pts-68, Pts-09, Pts-11, Pts-12, Pts-13, Pts-16, Pts19 and Pts-20 for the March 2003 campaign. These water points would result either from mixing phenomena with salt water or from basis exchange processes where calcium attaches to the clays and sodium is released into the water;

- Highly mineralized waters (TDS $>1000 \mathrm{mg} / \mathrm{L}$ ) with chloride sodium and potassium chemical facies represented by the water points: Pts-58, Pts08, Pts-09, Pts-17 and Pts-128 for the July 1998 campaign; Pts-07, Pts11 and Pts-114 for the July 2002 campaign and Pts-10, Pts-114 and Pts202 for the March 2003 campaign. These water points would result from the phenomena of salt intrusion or leaching of sea spray and marine aerosols during the infiltration of rainwater into the subsoil.

In sub-domain 7, alkaline metals dominate alkaline earth metals and strong acid anions dominate weak acid anions. Water generally causes salinity problems for both irrigation and drinking. These waters are generally sodium chloride or sodium sulfate and are the result of saline intrusion or leaching from sea spray or aerosols. The water points are divided into two types:

- Moderately mineralized waters (TDS $<1000 \mathrm{mg} / \mathrm{L}$ ) with sodium and potassium bicarbonate chemical facies, represented by water points : Pts-01, Pts-04, Pts-07, Pts-11, Pts-13 and Pts-202 for the July 1998 campaign; Pts-3, Pts-02, Pts-04, Pts-08, Pts-10, Pts-12, Pts-16, Pts-19 and Pts-58 for the July 2002 campaign and Pts-02, Pts-04, Pts-08, Pts14 and Pts-15 for the March 2003 campaign.

- Highly mineralized waters (TDS > $1000 \mathrm{mg} / \mathrm{L}$ ) with sodium and potassium bicarbonate chemical facies represented by the water points: Pts-02, Pts-06, Pts-14 and PZ-03 for the July 1998 campaign; Pts-01 and Pts-03 for the July 2002 campaign and Pts-01 and Pts-03 for the March 2003 campaign. 


\section{Conclusion}

The physico-chemical study of groundwater in the environment of Lake Mbeubeuss, along the North Atlantic coast of Senegal reveals that an aquifer whose waters have an acidic to neutral $\mathrm{pH}$ and water temperature values close to those of the ambient temperature because of the configuration of the aquifer making it vulnerable to surface pollution. The waters in this aquifer are moderately to highly mineralized with chemical facies dominated by sodium and potassium chloride and calcium chloride facies, related both to the nature of the aquifer and to the environment (the sea and the discharge).

The study of the relationship between the major chemical elements and the chloride ion has made it possible to specify, on the one hand, the sources of mineralization and, on the other hand, the processes that control this mineralization of the groundwater in the Lake Mbeubeuss sector. Indeed, the situation close to the sea would suggest a considerable contribution of salts by marine aerosols and sea spray and to this contribution would be added the influence of the old deposits of the lake Mbeubeuss dried out by evaporation. The infiltration of effective rainwater contributes to the increase of groundwater mineralization.

The representation in Chadha's modified diagram of the chemical analyses of the groundwater of the three sampling campaigns has made it possible to highlight the different processes controlling the mineralization of the groundwater in the Lake Mbeubeuss sector : the phenomena of dissolution of carbonated, evaporitic and/or sulphated minerals; the phenomena of inverse basis exchange between water and aquifer; the phenomena of mixing of water or basis exchange processes between water and aquifer and the phenomena of saline intrusion and/or leaching of sea spray or aerosols during the infiltration of rainwater and point pollution by the public discharge.

\section{References}

[1] A.A. Les Landes, Impact of climate variations on hydrogeological resources, Doctoral Thesis, University of Reindeer, France, 2014.

[2] A.H. Dorsouma, M. Requier-des Jardins, Variabilité climatique, désertification et biodiversité en Afrique : s'adapter, une approche intégrée [Climate variability, desertification and biodiversity in Africa: adapting, an integrated approach], Vertigo-la revue électronique en sciences de l'environnement 8(1) (2008) 5356

[3] E.O. Hounsounou, M. Agassounon Djikpo Tchibozo, N.C. Kelome, E.W. Vissin, G. A. Mensah, E. Agbossou, Pollution des eaux à usages domestiques dans les milieux urbains défavorisés des pays en développement : Synthèse bibliographique [of domestic water in disadvantaged urban areas of developing countries: A bibliographical synthesis, Int. J. Biol. Chem. Sci. 10(5) (2016) 2392-2412.

[4] Y. Ma, I. Szostkiewicz, A. Korte, D. Moes, Y. Yang, A. Christmann, E. Grill, Regulators of PP2C phosphatase activity function as abscisic acid sensors, Sci. 324 (2009) 1064-1068

[5] O.F. Essouli, Impact de la décharge public du lac Mbeubeuss sur les ressources en eau de l'aquifère des sables quaternaires de Thiaroye, [Impact of the public discharge of Lake Mbeubeuss on the water resources of the Thiaroye Quaternary Sands Aquifer], Thèse de doctorat 3ème cycle, Département de Géologie, Faculté des Sciences et Techniques, Université Cheikh Anta Diop de Dakar (Sénégal), 2005.

[6] A.A. Tandia, évolution et migration des formes de l'azote minéral dans les aquifères situés sous environnement périurbain non assaini : Cas de la nappe des quaternaires de la région de Dakar (Sénégal), [Origin, evolution and migration of forms of mineral nitrogen in aquifers located under unhealthy peri-urban environment: Case of the Quaternary aquifer of the Dakar region (Senegal)], Thèse doctorat d'Etat es-Sciences, Département de Géologie, Université CAD, Dakar (Sénégal), 2000.

[7] S. Cissé Faye, Free table cloth of quaternary sands Thiaroye/Beer Thialane, Study of nitrate contamination on the basis of a geographic information system
(PC ARC/INFO), 3rd cycle Doctoral Thesis, Department of Geology, CAD University, Senegal, University of Munich, Germany, 2000.

[8] AM. Kouassi, KE Kouakou, E Ahoussi Kouassi, K.F. Kouame, J. Biemi, Application d'un modèle statistique a la simulation de la conductivité électrique des eaux souterraines: cas de l'ex-région du N'zi-comoé (Centre-est de la Côte d'ivoire), [Application of a statistical model to the simulation of the electrical conductivity of groundwater: case of the former region of N'zi-comoe (Central-eastern Ivory Coast)], Larhyss Jour. 32 (2017) 47-69.

[9] B.R. Scanlon, K.E. Keese, A.L. Flint, L.E. Flint, C.B. Gaye, et al., Global synthesis of groundwater recharge in semi-arid and arid regions, Hydrol. Process 20 (2006) 3335-3370.

[10] A. Faye, Recharge and paleo-recharge of deep aquifers in the Senegal Basin Contribution of stable and radioactive isotopes of the environment and paleo hydrogeological and paleoclimatic involvement, Doctoral Thesis of State esSciences, Department of Geology, CAD University, Dakar, Senegal, 1994.

[11] A. Martin, Les nappes de la presqu'île du Cap Vert. Leur utilisation pour l'alimentation en eau de Dakar [Aquifers of the peninsula of Cape Verde, Their use for the water supply of Dakar], BRGM Publication, Orléans, France, 1970.

[12] J. Tchani, L'aquifère des sables quaternaires au nord de la presqu'île de CapVert (Sénégal) : Morphologie déduite des données hydrogéologiques et géophysiques (sondage électriques). Analyse d'un cas d'invasion saline. Zone de Pikine [The quaternary sands aquifer north of the cape Verde peninsula (Senegal): Morphology deduced from hydrogeological and geophysical data (electrical sounding), Analysis of a case of saline invasion, Pikine Area] Mémoire DEA, Département de Géologie, Université CAD, Dakar (Sénégal), 1996.

[13] O.F. Essouli, Caractéristiques physiques, géologiques et hydrogéologiques du site du lac Mbeubeuss et ses environs. Paramètres hydrodynamiques et qualité des eaux [Physical, geological and hydrogeological characteristics of the Lake Mbeubeuss site and its surroundings, Hydrodynamic parameters and water quality]. Mémoire DEA, Département de Géologie, Faculté des Sciences et Techniques, Université Cheikh Anta Diop de Dakar (Sénégal), 2001.

[14] J.C. Kirchmer, Quality control in water analyses, Environ. Sci. Technol. 17(4) (1983) 178-181.

[15] W. Stumm, J. J. Morgan, Aquatic chemistry, $3^{\text {rd }}$ Edn., John Wiley \& Sons Inc, New York, 1996.

[16] Y. Travi, J.C. GAC, B. Fritz, Reconnaissance chimique et isotopique des eaux de pluie au Sénégal [Chemical and isotopic survey of rainwaters in Senegal], Géodynamiques 2 (1987) 43-53.

[17] A.H. Truesdell, B.F. Jones, WATEQ, a computer program for calculating chemical equilibrium of natural waters, J. Res. USGS 2(2) (1974) 233-239.

[18] L.N. Plummer, B.F. Jones, A.H. Truesdell, WateqF, a Fortran IV version of Wateq a computer program for calculating chemical equilibrium of natural waters, US Geological Survey Water-Resources Investigations Report 76(13) (1976) 1-61.

[19] K. Dindane, L. Bouchaou, Y. Hsissou, M. Krimissa, Hydrochemical and isotopic characteristics of groundwater in the Souss Upstream Basin, Southwestern Morocco, J. Afr. Earth Sci. 36(4) (2003) 315-327.

[20] O. Banton, L.M. Bangoy, S. Chevalier, P. Houenou, P. Lafrance, C. Rivard, Hydrogeology: Environmental multiscience of groundwater, University of Quebec Press, AUPELF, Canada, 1997.

[21] M.D. Fidelibus, L. Tulipano, Regional flow of intruding sea water in the carbonate aquifers of Apulia (Southem Italy), 14th Salt Water Intrusion Meeting, Malmo, Sweden, Reports and moddelanden, Geological Survey of Sweden, Uppsala, 1996, pp.230-241.

[22] J.H. Tellam, Hydrochemistry of the saline groundwaters of the lower Mersey Basin Permo-Triasssic Sandstone aquifer, UK, J. Hydrol. 165(1-4) (1995) 4584.

[23] M.G. Garcia, V. Del, M. Hidalgo, M.A. Blesa, Geochemistry of groundwater in the alluvial plain of Tucuman province, Argentina, Hydrogeol. J. 9(6) (2001) 597 610.

[24] M.C.w. Lean, j. Jankowski, n. Lavitt, Groundwater quality and sustainability in an alluvial aquifer, Australia, In: O. Sililo, et al. (Eds.), Groundwater, past achievement and future challenges, A.A. Balkema (Rotterdamm), Les Pays Bas, 2000, pp.567-573.

[25] S. Djenba, A. Boudoukila, S. Bencer, Hydrochemical approach to the surface aquifer of Ain Djacer, Eastern Algeria, Larhyss Jour. 34 (2013) 931-299.

[26] S.G. Eblin, G.M. Soro, A.P. Sombo, N. Aka, O. Kambire, N. Soro, (2014). Groundwater hydrochemistry in the Adiaké region (Southern Ivory Coast) Larhyss Jour. 14 (2014) 193-214.

[27] D.K. Chadha, A proposed new diagram for geochemical classification of natural waters and interpretation of chemical data, Hydrogeol. J. 7(5) (1999) 431-439. 